Article

\title{
Evaluation of Greenhouse Gas Emissions from Reservoirs: A Review
}

\author{
Ion V. Ion ${ }^{1}$ and Antoaneta Ene ${ }^{2, *(\mathbb{D})}$ \\ 1 Thermal Engines and Environmental Engineering Research Center, Faculty of Engineering, "Dunarea de Jos" \\ University of Galati, 800008 Galati, Romania; ion.ion@ugal.ro \\ 2 INPOLDE Research Center, Faculty of Sciences and Environment, ReForm-UDJG Multidisciplinary Platform, \\ "Dunarea de Jos" University of Galati, 800008 Galati, Romania \\ * Correspondence: Antoaneta.Ene@ugal.ro
}

check for updates

Citation: Ion, I.V.; Ene, A. Evaluation of Greenhouse Gas Emissions from Reservoirs: A Review. Sustainability 2021, 13, 11621. https://doi.org/ $10.3390 /$ su132111621

Academic Editors: Baojie He, Ayyoob Sharifi, Chi Feng and Jun Yang

Received: 24 August 2021

Accepted: 17 October 2021

Published: 21 October 2021

Publisher's Note: MDPI stays neutral with regard to jurisdictional claims in published maps and institutional affiliations.

Copyright: (c) 2021 by the authors. Licensee MDPI, Basel, Switzerland. This article is an open access article distributed under the terms and conditions of the Creative Commons Attribution (CC BY) license (https:// creativecommons.org/licenses/by/ $4.0 /)$.

\begin{abstract}
In order to evaluate the greenhouse gas (GHG) emissions from a reservoir or from several reservoirs in a country or a climatic zone, simpler or more complex models based on measurements and analyses of emissions presented in the literature were developed, which take into account one or more reservoir-specific parameters. The application of the models in the assessment of GHG emissions from a multipurpose reservoir gave values that are more or less close to the average values reported in the literature for the temperate zone reservoirs. This is explained by the fact that some models only consider emissions caused by impoundment and not degassing, spillway emissions, and downstream emissions, or those that use different calculation periods. The only model that calculates GHG emissions over the life cycle that occur pre-impoundment, post-impoundment, from unrelated anthropogenic sources and due to the reservoir construction is the model used by the G-res tool. In addition, this tool is best suited for multipurpose reservoirs because it allocates GHG emissions for each use, thus facilitating the correct reporting of emissions. The G-res tool used to calculate GHG emissions from the Stânca-Costești Multipurpose Reservoir shows that this is a sink of GHG with a net emission of $-5 \mathrm{~g} \mathrm{CO} 2 \mathrm{eq} / \mathrm{m}^{2} / \mathrm{yr}$ (without taking into account the emissions due to dam construction).
\end{abstract}

Keywords: emissions; greenhouse gas; multipurpose reservoirs; temperate climate

\section{Introduction}

Reservoirs are manmade lakes created by building dams on rivers for various purposes: flood control, electricity generation, irrigation, water supply, aquaculture, environmental services, recreational activities, navigation etc.

In freshwater ecosystems, several mechanisms are involved in the natural carbon cycle. They receive carbon from terrestrial ecosystems through drainage, capture the carbon through primary production, bury the carbon in sediments, emit GHG through biomass degradation and respiration, and transport the carbon downstream to the seas or oceans. GHG emissions can be increased by human activities around the ecosystem through sewage and agricultural pollution. Dams affect the natural carbon cycle in freshwater ecosystems through floods of terrestrial vegetation and soils. The flooded organic matter decomposes causing additional GHG emissions, especially in the first years after the reservoir creation. Flooding can also increase sedimentation and decomposition in the reservoir, due to longer water residence times, which can lead to higher GHG emissions [1]. In addition, reservoirs can have large fluctuations in the water level, especially hydroelectric reservoirs that store large volumes of water to be used during drought. It can, therefore, be said that artificial reservoirs differ from natural lakes by riverine nutrient inputs, the flooding of terrestrial organic carbon, and water-level fluctuations; they also may have different GHG emissions. Reservoirs present, from a social, economic and environmental point of view, not only advantages, but also disadvantages. 
Reservoir use can serve single or multiple purposes. According to the International Commission on Large Dams (ICOLD), 70\% of large reservoirs are designed for singlepurpose usage. Around $11 \%$ of large reservoirs have been built only for hydropower generation and $14 \%$ for hydropower generation plus other uses. These high figures show why GHG emissions from reservoirs should be accounted for. In addition, the study of these emissions indicates ways to reduce them.

The main greenhouse gases emitted by a reservoir are $\mathrm{CO}_{2}, \mathrm{CH}_{4}$ and $\mathrm{N}_{2} \mathrm{O}$. They have a different global warming potential (GWP). For the time period of 100 years, $\mathrm{GWP}$ for $\mathrm{CO}_{2}$ is 1 ; for $\mathrm{CH}_{4}$, it is 34 times higher than that of $\mathrm{CO}_{2}$, and for $\mathrm{N}_{2} \mathrm{O}$, it is 298 times that of $\mathrm{CO}_{2}$ [2].

The $\mathrm{CO}_{2}$ is generated by the decomposition of organic material and nutrients transported in the reservoir by affluent or by rainfall and overland flow, by the decomposition of dead organic matter stored in the soil of the reservoir, by the respiration of vegetation present in the reservoir, from $\mathrm{CO}_{2}$ dissolved in water and from the oxidation of $\mathrm{CH}_{4}$. The sediments in drawdown areas are also a source of $\mathrm{CO}_{2}$ emission, due to their exposure to air during water level fluctuations.

The emission of $\mathrm{CH}_{4}$ comes from the decomposition of organic matter and vegetation under anaerobic conditions in the soil or sediment layer of the reservoir.

Nitrous oxide $\left(\mathrm{N}_{2} \mathrm{O}\right)$ arises as a by-product of the aerobic nitrification reaction or of the anaerobic denitrification that occurs in lake riparian areas. The few measurements of $\mathrm{N}_{2} \mathrm{O}$ emission from reservoirs showed a variation similar to that of $\mathrm{CH}_{4}$ in terms of generation. The contribution of $\mathrm{N}_{2} \mathrm{O}$ to the total GHG emission expressed as an $\mathrm{CO}_{2}$ equivalent is low, compared to $\mathrm{CH}_{4}$ s i CO $\mathrm{CO}_{2}\left(\mathrm{~N}_{2} \mathrm{O}-17 \mathrm{mg} \mathrm{CO} 2 \mathrm{eq} / \mathrm{m}^{2} / \mathrm{d} ; \mathrm{CH}_{4}-275 \mathrm{mg} \mathrm{CO} \mathrm{CO}_{2 \mathrm{eq}} / \mathrm{m}^{2} / \mathrm{d}\right.$ and $\left.\mathrm{CO}_{2}-1585 \mathrm{mg} \mathrm{CO} / \mathrm{m}^{2} / \mathrm{d}\right)$ [3].

GHG $\left(\mathrm{CO}_{2}\right.$ and $\left.\mathrm{CH}_{4}\right)$ reaches the atmosphere through the following channels: diffusive flow from the reservoir surface, through degassing when passing through the hydraulic turbine and spillway (due to pressure drop), through diffusive flow at the downstream river surface. Methane can also reach the surface of the reservoir through bubbling in shallow areas of reservoir.

The main factors influencing GHG emissions are the carbon stock in soil and flooded biomass or that transported by the upstream rivers in reservoirs; the concentration of dissolved oxygen in the reservoir; water quality and nutrient content; the inflow and shape of the reservoir; the water depth and extension of the littoral zone; the wind speed at the reservoir surface; and the water temperature and configuration of dam intake and outlets [3]. These factors influence the biochemical processes of organic matter formation, respiration, methanogenesis, $\mathrm{CH}_{4}$ oxidation, gas exchange between the reservoir and the atmosphere. The GHG measurements showed a variation in time and space within a reservoir and also a seasonal variation and a decrease in general with the age of the reservoir.

There are many studies on the evaluation of GHG emissions from reservoirs, which differ by the methodologies used, the lifespan considered, and the size and type of reservoir [1,4-39].

Most studies have analyzed GHG emissions from hydropower reservoirs. The few studies performed on natural lakes have shown that there are no significant differences between reservoir surface emissions from hydropower reservoirs, compared to nonhydropower reservoirs [10]. At hydropower reservoirs, there are also degassing emissions, downstream emissions and emissions from drawdown zones.

From the analysis of GHG emissions from 85 different hydroelectric reservoirs with a global distribution, it was observed that all the reservoirs are sources of $\mathrm{CH}_{4}$ to the atmosphere, the majority $\left(88 \%\right.$ ) are also a source of $\mathrm{CO}_{2}$ (only $12 \%$ of reservoirs are net sinks of $\mathrm{CO}_{2}$ ) and that there is a large variation in emissions [5].

Knowing the GHG emissions generated by reservoirs is an important factor in making decisions to finance future projects and discerning how environmentally friendly they are.

The purpose of this study is to review the main methodologies for assessing GHG emissions from a reservoir, find the most appropriate model to estimate GHG emissions from a multipurpose reservoir, and present the complete environmental performance of 
a reservoir placed in the temperate zone of Eastern Romania, a country for which data are limited. On the Romanian territory, there are about 400 large reservoirs totaling 6300 million $\mathrm{m}^{3}$. The chosen Stânca-Costești reservoir is one of the representative reservoirs, being the second largest in the country.

The models used both for reservoirs for any purposes other than power generation and for hydropower reservoirs are presented. The results obtained are presented comparatively to help stakeholders in identifying and choosing the calculation method.

\section{Assessment of GHG Emissions from the Reservoirs}

Because measuring GHG emissions from reservoirs is not an easy task due to the large variation in time and space, especially of $\mathrm{CH}_{4}$ emissions, several methodologies for their evaluation were developed. All methodologies are based on measurements of emissions from reservoirs located in different climatic zones. The different emission values reported in the literature show the influence of specific reservoir factors, such as type, climate zone, age and depth of the reservoir, neighboring land cover types, land uses before flooding and others.

Table 1 shows the estimated GHG emissions from different types of reservoirs and freshwater ecosystems [10].

Table 1. GHG emissions from reservoirs and freshwater ecosystems [10].

\begin{tabular}{|c|c|c|c|}
\hline \multirow{2}{*}{ System Type } & \multicolumn{2}{|c|}{ GHG Areal Rate, $\left(\mathrm{mg} / \mathrm{m}^{2} / \mathrm{d}\right)$} & \multirow{2}{*}{$\begin{array}{c}\mathrm{CO}_{2} \text { Equivalent Emissions, } \mathrm{CO}_{2 \text { eq }} \\
\left(\mathrm{g} / \mathrm{m}^{2} / \mathrm{yr}\right)\end{array}$} \\
\hline & $\mathrm{CH}_{4}$ & $\mathrm{CO}_{2}$ & \\
\hline \multirow{2}{*}{ All reservoirs } & 160.8 & 1207.8 & 2436.38 \\
\hline & $110-128$ & 1822.68 & $2695.66-2253.76$ \\
\hline Hydroelectric reservoirs & $32.16-150$ & $1412-2415$ & $914.49-2742.98$ \\
\hline Lakes & 53.6 & 790.56 & 953.73 \\
\hline Ponds & 36.18 & 1544.52 & 1012.74 \\
\hline Rivers & $8-131$ & $29,111.64$ & $10,725.03-12,251.46$ \\
\hline Wetlands & $20-84$ & - & $248.20-1042.44$ \\
\hline
\end{tabular}

In paper [16], an average global GHG emission is reported (reservoir surface plus drawdown area emissions and reservoir downstream emissions) from the hydropower reservoirs of $92 \mathrm{~g} \mathrm{CO}_{2} / \mathrm{kWh}$ and $5.7 \mathrm{~g} \mathrm{CH}_{4} / \mathrm{kWh}$.

As stated in [32], the lifecycle GHG emissions from hydropower plants range from $1 \mathrm{~g}$ $\mathrm{CO}_{2 \mathrm{eq}} / \mathrm{kWh}$ to $2200 \mathrm{~g} \mathrm{CO}_{2 \mathrm{eq}} / \mathrm{kWh}$ with an average value of $24 \mathrm{~g} \mathrm{CO}_{2 \mathrm{eq}} / \mathrm{kWh}$.

A distribution by the source of GHG emission from hydropower reservoirs from different climatic zones is presented in Table $2[16,28]$. The large variation from one climate zone to another can be seen as well as the higher contribution of emissions from drawdown areas and the contribution of $\mathrm{CO}_{2}$ emissions to the total emissions.

Table 2. GHG emissions from hydroelectric reservoirs $[16,28]$.

\begin{tabular}{|c|c|c|}
\hline \multirow{2}{*}{ Climate Zone } & \multicolumn{2}{|c|}{ Carbon Emission, $\left(\mathrm{mg} / \mathrm{m}^{2} / \mathrm{d}\right)$} \\
\hline & $\mathrm{CO}_{2}$ & $\mathrm{CH}_{4}$ \\
\hline \multicolumn{3}{|c|}{ Reservoir surface } \\
\hline Boreal & 753 & 9.1 \\
\hline \multirow{2}{*}{ Temperate } & $1500[16]$ & $20[16]$ \\
\hline & $386[28]$ & $2.8[28]$ \\
\hline Tropical & 3097 & 91.3 \\
\hline \multicolumn{3}{|c|}{ Drawdown area } \\
\hline Temperate & 2110 & 110 \\
\hline \multirow{2}{*}{ Tropical } & 3500 [16] & 300 [16] \\
\hline & $13,000[28]$ & $235[28]$ \\
\hline
\end{tabular}

The contribution to GHG emissions related to reservoir construction, meaning those from the activities related to dam construction (raw material extraction, equipment manufacturing, transportation, and building process of dam), is estimated to be (2.3-37.9) $\mathrm{gCO}_{2 \mathrm{eq}} / \mathrm{kWh}$ [27]. 
In paper [26], an average global emission of $173 \mathrm{~kg} \mathrm{CO}_{2} / \mathrm{MWh}$ and $2.95 \mathrm{~kg} \mathrm{CH}_{4} / \mathrm{MWh}$ was estimated after the emissions from over 1400 hydroelectric power plants were analyzed. The study emphasizes the importance of analyzing each hydropower plant and the need for standardized measurement procedures, taking into consideration carbon burial, drawdown areas and methane bubbles. Additionally, in this paper [26], the following models were developed using generalized linear models:

- $\mathrm{CO}_{2}$ emission expressed in $\mathrm{kg} \mathrm{CO}_{2} / \mathrm{MWh}$ as a function of the area-to-electricity ratio (ATER, $\left.\mathrm{km}^{2} / \mathrm{GWh}\right)$ and reservoir area $\left(\mathrm{S}, \mathrm{km}^{2}\right)$ :

$$
\mathrm{CO}_{2}=-169.73+241.86 \times \mathrm{ATER}+120.34 \times \ln (\mathrm{S}), \mathrm{kg} \mathrm{CO}_{2} / \mathrm{MWh}
$$

- $\mathrm{CH}_{4}$ emission expressed in $\mathrm{kg} \mathrm{CH} / \mathrm{MWh}$ as a function of the reservoir age (A, years), area-to-electricity ratio (ATER, $\mathrm{km}^{2} / \mathrm{GWh}$ ) and maximum temperature $\left(\mathrm{T}_{\max },{ }^{\circ} \mathrm{C}\right)$ :

$$
\ln \left(\mathrm{CH}_{4}\right)=-9.81-0.75 \times \ln (\mathrm{A})+1.18 \times \ln (\mathrm{ATER})+4.5 \times \ln \left(\mathrm{T}_{\max }\right), \mathrm{kg} \mathrm{CH}_{4} / \mathrm{MWh}
$$

GHG emission expressed in $\mathrm{mg} \mathrm{C} / \mathrm{m}^{2} / \mathrm{d}$, which can also be used in the case of reservoirs with a use other than energy production, depending on the reservoir age (A, years), erosion rate $(\mathrm{Er}, \mathrm{t} / \mathrm{ha} / \mathrm{yr})$, reservoir area $\left(\mathrm{S}, \mathrm{km}^{2}\right)$ and maximum temperature $\left(\mathrm{T}_{\max },{ }^{\circ} \mathrm{C}\right)$ :

$$
\begin{gathered}
\mathrm{CO}_{2}=494.46-4.07 \times A+8.09 \times \mathrm{Er}, \mathrm{mg} \mathrm{CO} 2 / \mathrm{m}^{2} / \mathrm{d} \\
\ln \left(\mathrm{CH}_{4}\right)=-12.84-0.03 \times A+0.21 \times \ln (\mathrm{S})-0.01 \times \mathrm{Er}+4.88 \times \ln \left(\mathrm{T}_{\max }\right), \mathrm{mg} \mathrm{CH}_{4} / \mathrm{m}^{2} / \mathrm{d}
\end{gathered}
$$

In [5], $\mathrm{CO}_{2}$ and $\mathrm{CH}_{4}$ emissions from 85 reservoirs between $68^{\circ} \mathrm{N}$ and $25^{\circ} \mathrm{S}$ were analyzed. The reservoir surface emissions were estimated, correlated to reservoir age (A, years) and latitude $\left(\mathrm{L},{ }^{\circ}\right)$, dissolved organic carbon $(\mathrm{DOC}, \mathrm{mg} / \mathrm{L})$ and mean reservoir depth $(h, m)$. Based on the measured data, the $\mathrm{CO}_{2}$ and $\mathrm{CH}_{4}$ emissions were predicted, using the following multiple-regression equations:

$$
\begin{gathered}
\log \left(\mathrm{CO}_{2}+400\right)=3.06-0.16 \times \log (\mathrm{A})-0.01 \times \mathrm{L}+0.41 \times \log (\mathrm{DOC}), \mathrm{mg} \mathrm{CO}_{2} / \mathrm{m}^{2} / \mathrm{d} \\
\log \left(\mathrm{CH}_{4}\right)=1.33-0.36 \times \log (\mathrm{A})-0.32 \times \log (\mathrm{h})+0.39 \times \log (\mathrm{DOC})-0.01 \mathrm{~L}, \mathrm{mg} \mathrm{CH}_{4} / \mathrm{m}^{2} / \mathrm{d}
\end{gathered}
$$

Ref. [38] presented a calculation tool called HydroCalculator, which, in addition to calculating financial indicators, also calculates greenhouse gas emissions. The biome carbon loss (BCL) model based on the initial carbon stock is used to calculate GHG emissions:

$$
\mathrm{C}_{\mathrm{t}}=\mathrm{C}_{0}\left(\frac{\mathrm{e}^{-0.3 \mathrm{t}}}{5}+\frac{\mathrm{e}^{-0.03 \mathrm{t}}}{3}+\frac{1}{2}\right) \text {, tonne } \mathrm{C} / \mathrm{yr}
$$

where $\mathrm{C}_{\mathrm{t}}$ is the amount of carbon $\left(\mathrm{CO}_{2}\right.$ and $\left.\mathrm{CH}_{4}\right)$ in tonnes in the year $\mathrm{t}, \mathrm{C}_{0}$ is the initial amount of organic carbon in soil and vegetation in tonnes, and $t$ is the time in years.

This model calculates only GHG emissions from the decomposition of organic matter, not GHG emissions from turbines and spillway.

Paper [38] calculated the proportion of carbon emitted as $\mathrm{CO}_{2}$ and $\mathrm{CH}_{4}$, observing that $\mathrm{CO}_{2}$ emissions are $73 \%$ of carbon emissions and $\mathrm{CH}_{4}$ emissions are $27 \%$. Carbon emissions can be converted to $\mathrm{CO}_{2}$ and $\mathrm{CH}_{4}$ by multiplying the values by $44 / 12$ and $16 / 12$, respectively. $\mathrm{CH}_{4}$ emissions are converted to $\mathrm{CO}_{2}$ equivalents by multiplying the global warming potential of $\mathrm{CH}_{4}$ specified in IPCC's Fifth Assessment Report [33].

Ref. [39] presented, in addition to Equation (7), two other calculation equations of $\mathrm{CH}_{4}$ emissions, from the organic matter cycle (OMC model) (Equation (8)) and downstream emissions (from turbines and spillways) (downstream emission model) (Equation (9)):

$$
\begin{gathered}
\mathrm{E}_{\mathrm{OMCM}}=10\left(15.5 \mathrm{~S}^{0.841}+1.73 \mathrm{~S}^{0.927}+35.2 A^{0.649}\right), \mathrm{g} \mathrm{CH}_{4} / \mathrm{yr} \\
\mathrm{E}_{\mathrm{DEM}}=\mathrm{Q} \times \mathrm{d} \times \mathrm{c} \times \mathrm{t}, \mathrm{g} \mathrm{CH}_{4} / \mathrm{yr}
\end{gathered}
$$


where $\mathrm{S}$ is the reservoir surface area $\left(\mathrm{m}^{2}\right)$; $\mathrm{Q}$ is the waterflow $\left(\mathrm{m}^{3} / \mathrm{d}\right)$; $\mathrm{d}$ is the effective emission assumed to be $50 \%$ to $80 \%$; c is the $\mathrm{CH}_{4}$ concentration in turbine/spillway water intakes $\left(\mathrm{g} / \mathrm{m}^{3}\right)$; and $\mathrm{t}$ is the annual operation of spillways ( $1 / 4$ year) and turbines ( $3 / 4$ year) (days).

In paper [6], their own measurements of methane emissions from reservoirs were analyzed together with the emissions from 49 other reservoirs from temperate and boreal zones in order to find the best mathematical relations for estimating emissions according to the characteristics of the reservoirs. The following regression equations for bubbling, diffusive and storage emissions were proposed:

- $\mathrm{CH}_{4}$ bubbling emission:

$$
\left.\left(\mathrm{CH}_{4}\right)_{\text {bub }}=10^{0.838+0.934 \times \log (\mathrm{S})+0.881 \times \log (\mathrm{TP})}, \mathrm{g} \mathrm{CH}_{4} / \mathrm{yr}\right)
$$

- $\mathrm{CH}_{4}$ diffusive emission:

$$
\left(\mathrm{CH}_{4}\right)_{\text {diff }}=10^{0.234+0.927 \times \log (\mathrm{S})}, \mathrm{g} \mathrm{CH}_{4} / \mathrm{yr}
$$

- $\mathrm{CH}_{4}$ storage emission:

$$
\left(\mathrm{CH}_{4}\right)_{\text {stor }}=10^{7.068+3.304 \times \log (\mathrm{TP})-1.904 \times \log (\mathrm{DOC})}, \mathrm{g} \mathrm{CH}_{4} / \mathrm{yr}
$$

where $\mathrm{S}$ is the reservoir area $\left(\mathrm{m}^{2}\right), \mathrm{TP}$ is the concentration of total phosphorous $(\mu \mathrm{mol} / \mathrm{L})$, and DOC is the concentration of dissolved organic carbon $(\mathrm{mg} \mathrm{C} / \mathrm{L})$.

The International Energy Agency Hydropower Implementing Agreement on Hydropower Technologies and Programs (IEA Hydro) developed a framework, which describes the steps for data collection and analysis and the modeling tools to estimate the GHG emissions from a reservoir on the principles of net emissions defined by the IPCC. The estimation of GHG emissions from reservoirs is based on the analysis of the collected data and four elements of the new reservoir projects (flooded area, reservoir, upstream catchment area, reservoir outflow facilities, downstream river) [35].

The International Government Panel on Climate Change guidelines [2] recommend estimating the diffusion emission of $\mathrm{CO}_{2}$ from reservoirs by using the following equation:

$$
\left(\mathrm{CO}_{2}\right)_{\text {diff }}=\mathrm{P} \times \mathrm{E}\left(\mathrm{CO}_{2}\right)_{\text {diff }} \times \mathrm{S} \times 10^{-3} \text {, tonne } \mathrm{CO}_{2} / \mathrm{yr}
$$

where $\left(\mathrm{CO}_{2}\right)_{\text {diff }}$ is the total $\mathrm{CO}_{2}$ emission from the reservoir, tonne $\mathrm{CO}_{2} / \mathrm{yr} ; \mathrm{P}$ is the number

\begin{tabular}{|c|c|}
\hline Climate & $\begin{array}{c}\text { Diffusive Emission (Ice-Free Period) } \\
\mathrm{E}\left(\mathrm{CO}_{2}\right)_{\text {diff }}(\mathrm{kg} \mathrm{CO} / \mathrm{ha} / \mathrm{d}) \\
\text { Range and Median Values }\end{array}$ \\
\hline Boreal wet & (0.8-34.5) 11.8 \\
\hline Cold temperate, moist & (4.5-86.3) 15.2 \\
\hline Warm temperate, moist & $(-10.3-57.5) 8.1$ \\
\hline Warm temperate, dry & $(-12.0-31.0) 5.2$ \\
\hline Tropical, wet & (11.5-90.9) 44.9 \\
\hline Tropical, dry & (11.7-58.7) 39.1 \\
\hline
\end{tabular}
of days without ice cover during a year, days/yr; and $\mathrm{E}(\mathrm{CO} 2)$ diff is the average daily diffusive emissions, $\mathrm{kg} \mathrm{CO} 2 / \mathrm{ha} / \mathrm{d}$ (Table 3).

Table 3. $\mathrm{CO}_{2}$ measured emissions for flooded land [2].

To these emissions must be added the degassing emissions, which represent up to $30 \%$ of the total $\mathrm{CO}_{2}$ emissions from reservoirs in a temperate moist region and less than $5 \%$ in cold temperate regions.

For a preliminary estimate of the total annual $\mathrm{CH}_{4}$ emissions (reservoir surface emissions plus emissions originating from reservoir but emitted downstream of dam) from reservoirs older than 20 years, the 2019 Refinement to the 2006 IPCC Guidelines for National Greenhouse Gas Inventories, Volume 4: Agriculture, Forestry and Other Land Use 
(Chapter 7: Wetlands) [36] recommend the following equation with the emission factors derived from the G-Res model given in Table 2:

$$
\left(\mathrm{CH}_{4}\right)_{\text {tot }}=\left(\mathrm{CH}_{4}\right)_{\text {res }}+\left(\mathrm{CH}_{4}\right)_{\text {downstream }}=\alpha \times \mathrm{EF}_{\mathrm{CH}_{4}} \times \mathrm{S}+\alpha \times \mathrm{EF}_{\mathrm{CH}_{4}} \times \mathrm{S} \times \mathrm{R}_{\mathrm{d}}, \mathrm{kg} \mathrm{CH}_{4} / \mathrm{yr}
$$

where $\left(\mathrm{CH}_{4}\right)_{\text {res }}$ is the annual reservoir surface emissions of $\mathrm{CH}_{4}$ from reservoirs $>20$ years old, $\mathrm{kg} \mathrm{CH} / \mathrm{yr} ;\left(\mathrm{CH}_{4}\right)_{\text {downstream }}$ is the annual emissions of $\mathrm{CH}_{4}$ emitted downstream of dam, $\mathrm{kg} \mathrm{CH} / \mathrm{yr} ; \mathrm{EF}_{\mathrm{CH} 4}$ is the emission factor for $\mathrm{CH}_{4}$ emitted from the reservoir surface, $\mathrm{kg} \mathrm{CH}_{4} / \mathrm{ha} / \mathrm{yr}$ (Table 4); $\mathrm{R}_{\mathrm{d}}$ is a constant equal to the ratio of total downstream emission of $\mathrm{CH}_{4}$ to the total flux of $\mathrm{CH}_{4}$ from the reservoir surface, (median value of $\mathrm{R}_{\mathrm{d}}$ is 0.09 ); $\alpha$ is the emission factor adjustment for the trophic state in the reservoir (it can be estimated from the trophic index (TI), total phosphorus (TP), total nitrogen (TN) and Secchi depth (SD), and mean annual chlorophyll-a concentration in the reservoir (Chl-a)) (Table 5).

Table 4. $\mathrm{CH}_{4}$ Emission factors $\mathrm{EF}_{\mathrm{CH} 4}$ age $>20$ [36].

\begin{tabular}{cc}
\hline Climate Zone & Average Values $\left(\mathbf{k g ~ C H}_{\mathbf{4}} / \mathbf{h a} / \mathbf{y r}\right)$ \\
\hline Cool temperate & 54.00 \\
Warm temperate/dry & 150.90 \\
Warm temperate/moist & 80.30 \\
\hline
\end{tabular}

Table 5. Relationship between TI, Chl-a, TP, TN, SD, trophic class and trophic state adjustment factor [36].

\begin{tabular}{|c|c|c|c|c|c|c|}
\hline TI & $\begin{array}{l}\text { Chl-a } \\
(\mu g / L)\end{array}$ & $\begin{array}{c}\text { TP } \\
(\mu g / L)\end{array}$ & $\begin{array}{c}\mathrm{TN} \\
(\mu \mathrm{g} / \mathrm{L})\end{array}$ & $\begin{array}{l}\text { SD } \\
(\mathrm{m})\end{array}$ & $\begin{array}{c}\text { Trophic } \\
\text { Class }\end{array}$ & $\begin{array}{c}\text { Trophic State } \\
\text { Adjustment Factor, } \alpha \\
\text { Range and } \\
\text { Recommended Values }\end{array}$ \\
\hline$<30-40$ & $0-2.6$ & $0-12$ & $-<350$ & $>4$ & Oligotrophic & $0.7(0.7)$ \\
\hline $40-50$ & $2.6-20$ & $12-24$ & $-350-650$ & $2-4$ & Mesotrophic & $0.7-5.3(3)$ \\
\hline $50-70$ & $20-56$ & $24-96$ & $650-1200$ & $0.5-2$ & Eutrophic & 5.3-14.5 (10) \\
\hline 70-100+ & $56->155$ & $96->384$ & $>1200$ & $<0.5$ & Hypereutrophic & $14.5-39.4(25)$ \\
\hline
\end{tabular}

Paper [36] also recommends the use of the greenhouse gas reservoir (G-res) model as "currently the only easily and widely applicable model" that uses empirical relationships between environmental drivers and emissions to estimate reservoir GHG fluxes. The International Hydropower Association (IHA) in cooperation with the UNESCO Chair in Global Environmental Change has developed a detailed measurement guide for net GHG assessment [37] and the powerful and user-friendly G-res tool to assess GHG emissions [21]. Scientists from the University of Quebec at Montreal (UQAM), the Norwegian Foundation for Scientific and Industrial Research (SINTEF) and the Natural Resources Institute of Finland (LUKE) have also contributed to the development of the G-res tool [22]. The free online G-res tool (https: / / g-res.hydropower.org/ accessed on 5 May 2021) estimates the GHG emissions resulting from the impoundment of an existing or planned reservoir and emissions related to human activities and infrastructure. The modeling of GHG emissions (diffusive $\mathrm{CO}_{2}$ flux, diffusive $\mathrm{CH}_{4}$ flux, bubbling of $\mathrm{CH}_{4}$ and $\mathrm{CH}_{4}$ degassing) is based on the statistical analysis of gross emissions from 223 reservoirs in all climatic zones considering the following key governing variables: temperature, reservoir age, littoral area, solar radiance, phosphorous concentration in the reservoirs, soil carbon content, operating regime of reservoir, climate zone, land cover, reservoir area and soil type. The user of the G-res tool should prepare the input data before accessing the tool. The estimated net annual GHG emissions from a hydropower reservoir result from subtracting the pre-impoundment emissions and emissions from the reservoir due to unrelated anthropogenic sources (activities within the catchment as sources of nutrients and carbon flowing into the reservoir) from the post-impoundment emissions. The total annual GHG emissions are calculated by adding to the net annual emissions the emissions related to reservoir construction. 


\section{Case Study: The Stânca-Costești Multipurpose Reservoir}

The Stânca-Costeşti (Figure 1) multipurpose reservoir is located on the middle course of the Prut River, on the border between Romania and the Republic of Moldova. It was built between 1973 and 1978. It has an area of 6000 ha at normal retention level (NRL) and a maximum volume of 1400 million $\mathrm{m}^{3}$. In the Romanian Register of Large Dams, the Stânca-Costeşti reservoir appears on the 49th place in order of height and on the second place, according to the useful volume of the reservoir $\left(1290\right.$ million $\mathrm{m}^{3}$, after the Iron Gates I with 2100 million $\mathrm{m}^{3}$ ). The length of the reservoir, at normal retention level (NRL $90.80 \mathrm{~m}$ ), is $70 \mathrm{~km}$, and the length at maximum level (Nmax $99.50 \mathrm{~m}$ ) is $90 \mathrm{~km}$. The surface of the reservoir at normal retention level (NRL), is of 6000 ha and at maximum level (Nmax) is of 9200 ha. The reservoir has a reserve provided for flood control of 550 million cubic meters, which ensures the removal from flood risk of 100,000 ha of agricultural land, irrigation of 140,000 ha (70,000 on each shore), ensuring the necessary flows for water supply downstream $\left(10-16 \mathrm{~m}^{3} / \mathrm{s}\right)$ and energy production with the help of two power plants with a hydro unit of $15 \mathrm{MW}$, at a flow rate of $2 \times 65 \mathrm{~m}^{3} / \mathrm{s}$ with an average annual energy supply of $2 \times 65$ GWh $[40,41]$.

To build the reservoir, eight villages were relocated on both banks of the Prut River. The surface of the river basin of the Prut River in the Stânca-Costesti section is about $12,000 \mathrm{~km}^{2}$, and the average multiannual flow is $81 \mathrm{~m}^{3} / \mathrm{s}$.

The dam, made of concrete and local materials, uses the favorable morphological situation due to the presence of calcareous reefs, which reduce the average width of the major riverbed from 3-4 $\mathrm{km}$ to $400 \mathrm{~m}$.

The GHG emission from the multipurpose reservoir Stânca -Costești is estimated by using the above mentioned modeling methodologies and the powerful web-based tool G-res. The input data required by the G-res tool are given in Table 6, and the input data for the other models are the following: dissolved organic carbon concentration in reservoir water $(\mathrm{DOC}=6.5 \mathrm{mg} / \mathrm{L})$, maximum temperature $\left(\mathrm{T}_{\max }=30^{\circ} \mathrm{C}\right)$; ice-free period $(\mathrm{IFP}=319$ days $/ \mathrm{yr})$; mean annual chlorophyll-a concentration in reservoir (Chl-a $=10 \mathrm{mg} / \mathrm{L}$ ) [41] organic carbon in soil and vegetation $\left(C_{0}=50\right.$ tonne $\left.C / h a\right)$ [42]; erosion rate $(\mathrm{Er}=0.5 \mathrm{t} / \mathrm{ha} / \mathrm{yr})$ [43]; and concentration of total phosphorous in reservoir water $(\mathrm{TP}=0.97 \mu \mathrm{mol} / \mathrm{L})$.

To determine the average water volume of the Stânca-Costeşti reservoir, the daily records made by the "Romanian Waters" National Administration ("Prut-Bârlad" Water Basin Administration) in the period 2002-2018 were used.

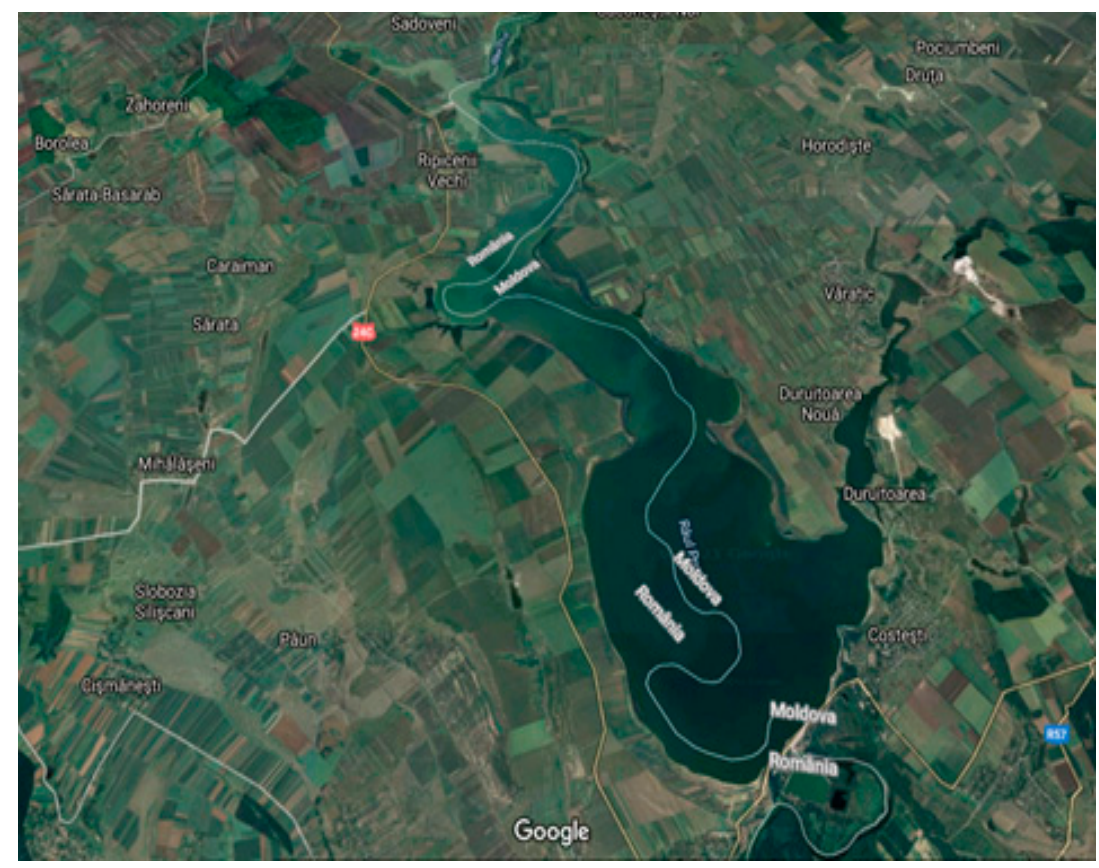

Figure 1. Cont. 


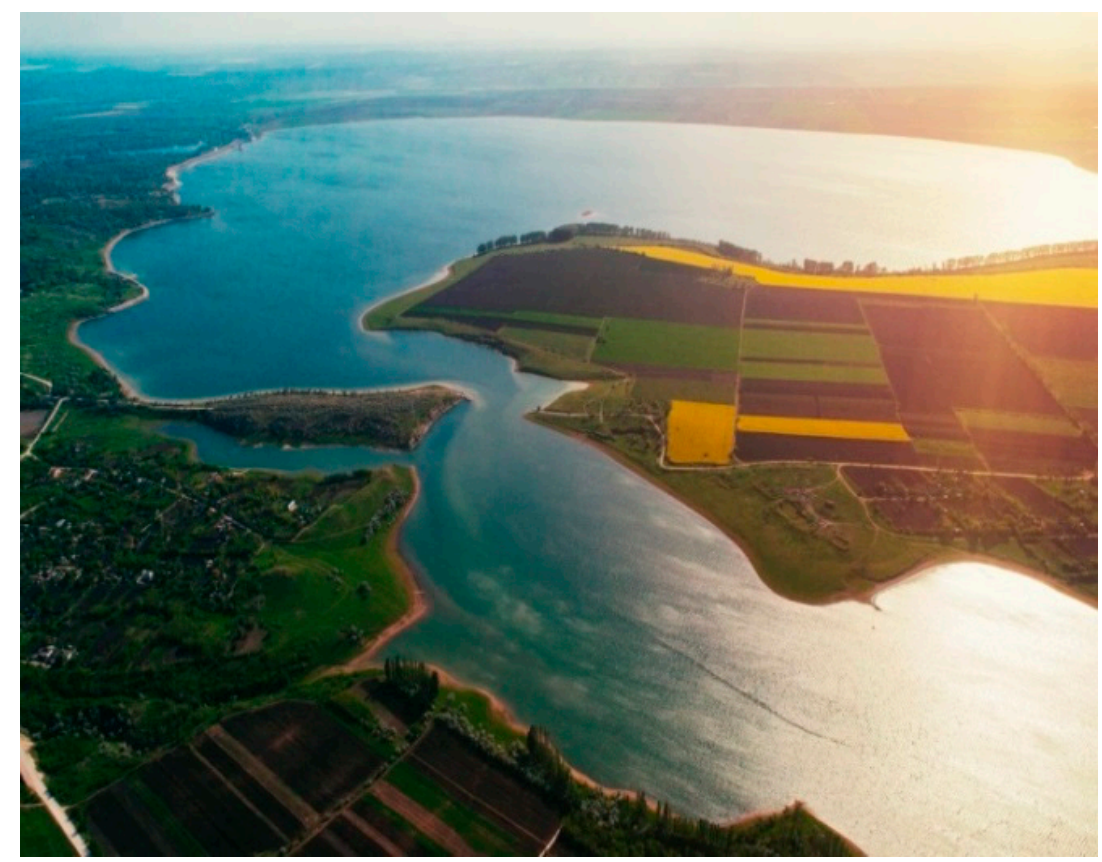

Figure 1. Stânca-Costesti multipurpose reservoir. Reprinted with permission from ref. [44]. Copyright 2021 www.planiada.ro (accessed on 15 January 2021).

Table 6. Data on the multipurpose reservoir Stânca-Costești [45].

\begin{tabular}{|c|c|c|}
\hline Catchment Information & \multicolumn{2}{|c|}{ Value } \\
\hline Catchment area & \multicolumn{2}{|c|}{$12,000 \mathrm{~km}^{2}$} \\
\hline Population in the catchment & \multicolumn{2}{|c|}{150,000} \\
\hline Precipitation & \multicolumn{2}{|c|}{$380 \mathrm{~mm} / \mathrm{yr}$} \\
\hline Catchment annual runoff & \multicolumn{2}{|c|}{$10 \mathrm{~m}^{3} / \mathrm{s}[46]$} \\
\hline Community wastewater treatment & \multicolumn{2}{|c|}{ None } \\
\hline Industrial wastewater treatment & \multicolumn{2}{|c|}{ None } \\
\hline Land cover in the catchment area & Post-impoundment & Pre-impoundment \\
\hline Croplands & $64 \%$ & $64 \%$ \\
\hline Grassland & $18 \%$ & $19 \%$ \\
\hline Forest & $16 \%$ & $16 \%$ \\
\hline Water bodies & $2 \%$ & $1 \%$ \\
\hline \multicolumn{3}{|c|}{ Reservoir Information } \\
\hline Country & \multicolumn{2}{|c|}{ Romania } \\
\hline Longitude of dam & \multicolumn{2}{|c|}{$27^{\circ} 14^{\prime} 00^{\prime \prime} \mathrm{E}$} \\
\hline Latitude of dam & \multicolumn{2}{|c|}{$47^{\circ} 51^{\prime} 30^{\prime \prime} \mathrm{N}$} \\
\hline Climate zone & \multicolumn{2}{|c|}{ Temperate } \\
\hline Water uses & \multicolumn{2}{|c|}{$\begin{array}{c}\text { flood control, water supply }\left(10 \mathrm{~m}^{3} / \mathrm{s}\right) \text {, irrigation }\left(0.8 \mathrm{~km}^{3} / \mathrm{yr}\right), \\
\text { hydroenergy, aquaculture }\left(2.9 \mathrm{~m}^{3} / \mathrm{s}\right)\end{array}$} \\
\hline Impoundment year & \multicolumn{2}{|c|}{1978} \\
\hline Power generation & \multicolumn{2}{|c|}{$30 \mathrm{MW}$} \\
\hline Power connection & \multicolumn{2}{|c|}{$110 \mathrm{~V}$} \\
\hline Yearly electricity generation & \multicolumn{2}{|c|}{$130 \mathrm{GWh}$} \\
\hline Reservoir area & \multicolumn{2}{|c|}{$59 \mathrm{~km}^{2}$} \\
\hline Reservoir volume (multiannual average) & \multicolumn{2}{|c|}{$1.4 \mathrm{~km}^{3}$} \\
\hline Water Level (m above sea level) & \multicolumn{2}{|c|}{$126 \mathrm{~m}$} \\
\hline Maximum depth & \multicolumn{2}{|c|}{$32 \mathrm{~m}$} \\
\hline Mean depth & \multicolumn{2}{|c|}{$23.33 \mathrm{~m}$ (Calculated by the G-res Tool) } \\
\hline Littoral area & \multicolumn{2}{|c|}{$3.59 \%$ (Calculated by the G-res Tool) } \\
\hline Water intake depth & \multicolumn{2}{|c|}{$28 \mathrm{~m}$} \\
\hline Soil carbon content under impounded area & \multicolumn{2}{|c|}{$0.8 \mathrm{~kg} \mathrm{C} / \mathrm{m}^{2}$} \\
\hline Annual wind speed at $10 \mathrm{~m}$ & \multicolumn{2}{|c|}{$6.6 \mathrm{~m} / \mathrm{s}$} \\
\hline Water residence time & \multicolumn{2}{|c|}{$11.68 \mathrm{yr}$ (Calculated by the G-res Tool) } \\
\hline Annual discharge from the reservoir & \multirow{2}{*}{\multicolumn{2}{|c|}{$\begin{array}{c}3.8 \mathrm{~m}^{3} / \mathrm{s} \text { (Calculated by the G-res Tool) } \\
70,000 \mathrm{~m}\end{array}$}} \\
\hline River Length before Impoundment (m) & & \\
\hline Reservoir mean global horizontal radiance & \multicolumn{2}{|c|}{$3.24 \mathrm{kWh} / \mathrm{m}^{2} / \mathrm{d}$} \\
\hline Mean annual air temperature & \multicolumn{2}{|c|}{$13.3^{\circ} \mathrm{C}$} \\
\hline
\end{tabular}


Table 6. Cont.

\begin{tabular}{|c|c|}
\hline Catchment Information & Value \\
\hline \multicolumn{2}{|c|}{ Construction information } \\
\hline $\begin{array}{l}\text { Material excavated and/or used } \\
\text { for construction }\end{array}$ & $500,000 \mathrm{~m}^{3}$ \\
\hline $\begin{array}{l}\text { All concrete brought to site for the dam, } \\
\text { tunnels, foundations }\end{array}$ & $4,000,000 \mathrm{~m}^{3}$ \\
\hline $\begin{array}{c}\text { All steel brought to site for reinforcement, } \\
\text { pipelines, mechanical and } \\
\text { electrical equipment }\end{array}$ & 5000 tonne \\
\hline
\end{tabular}

\section{Results and Discussions}

Using the models presented above and the G-res tool to evaluate the GHG emissions from the Stânca-Costești multipurpose reservoir, we obtained the results given in Table 7.

Table 7. Comparison of different approaches to estimate reservoir emissions.

\begin{tabular}{|c|c|c|c|c|c|c|c|c|c|c|}
\hline \multirow{3}{*}{\multicolumn{2}{|c|}{ Model }} & \multicolumn{9}{|c|}{ Emissions } \\
\hline & & \multicolumn{3}{|c|}{$\mathrm{CO}_{2}$} & \multicolumn{3}{|c|}{$\mathrm{CH}_{4}$} & \multicolumn{3}{|c|}{$\begin{array}{c}\mathrm{CO}_{2 \mathrm{eq}} \\
\left(\mathrm{GWP}_{100} \text { for } \mathrm{CH}_{4}=34\right)\end{array}$} \\
\hline & & $\mathrm{mg} / \mathrm{m}^{2} / \mathrm{d}$ & kg/MWh & tonne/yr & $\mathrm{mg} / \mathrm{m}^{2} / \mathrm{d}$ & kg/MWh & tonne/yr & $\mathrm{mg} / \mathrm{m}^{2} / \mathrm{d}$ & kg/MWh & tonne/yr \\
\hline \multicolumn{2}{|c|}{ Scherer 2016 [26] } & 327.56 & 155.88 & - & 28.57 & 5.93 & - & 1298.94 & 210.72 & $27,972.67$ \\
\hline \multicolumn{2}{|c|}{ Barros 2011 [5] } & 414.35 & - & - & 1.15 & - & - & 453.65 & 73.59 & 9769.44 \\
\hline \multicolumn{2}{|c|}{ IPCC 2006 [2] } & 520 & - & $10,124.4$ & - & - & - & 520 & 77.88 & $10,124.4$ \\
\hline \multicolumn{2}{|c|}{ IPCC 2019 [36] } & - & - & - & 13.11 & - & 287.10 & 445.73 & 72.31 & 9761.40 \\
\hline \multicolumn{2}{|r|}{ Total } & 520 & - & $10,124.4$ & 13.11 & - & 287.10 & 965.73 & 150.19 & $19,885.80$ \\
\hline \multirow{4}{*}{$\begin{array}{l}\text { Bastviken } \\
2004[6]\end{array}$} & Bubbling & - & - & - & 2.46 & - & 53.88 & 83.65 & 13.57 & 1831.91 \\
\hline & Diffusion & - & - & - & 1.27 & - & 27.82 & 43.19 & 7.01 & 945.86 \\
\hline & Storage & - & - & - & 0.18 & - & 3.93 & 6.10 & 0.99 & 133.51 \\
\hline & Total & - & - & - & 3.91 & - & 85.63 & 132.93 & 21.56 & 2911.27 \\
\hline \multicolumn{2}{|c|}{ Vilela 2017 [38] } & - & - & 1141.04 & 19.27 & - & 422.03 & 3497.3 & 567.34 & $15,490.06$ \\
\hline \multirow{2}{*}{$\begin{array}{c}\text { Bergier } \\
2007 \text { [39] }\end{array}$} & OMCM & - & - & - & 39.24 & - & 859.321 & 1334.11 & 216.42 & $29,216.91$ \\
\hline & DEM & - & - & - & 18.25 & - & 399.72 & 620.57 & 100.67 & $13,590.48$ \\
\hline \multirow{4}{*}{$\begin{array}{l}\text { G-res tool } \\
\text { [22] }\end{array}$} & $\begin{array}{l}\text { Post- } \\
\text { impoundment }\end{array}$ & 205.48 & - & 4425.00 & 2.98 & - & 64.21 & 306.85 & 50.83 & 6608.00 \\
\hline & $\begin{array}{l}\text { Pre- } \\
\text { impoundment }\end{array}$ & 216.44 & - & 4661.00 & 3.06 & - & 65.94 & 320.55 & 53.10 & 6903.00 \\
\hline & $\begin{array}{c}\text { Unrelated } \\
\text { Anthropogenic } \\
\text { Source (UAS) }\end{array}$ & 0.00 & - & 0.00 & 2.98 & - & 64.21 & 101.37 & 16.79 & 2183.00 \\
\hline & $\begin{array}{l}\text { Net reservoir } \\
\text { emission }\end{array}$ & -10.96 & 0.00 & -236.00 & -3.06 & 0.00 & -65.94 & -115.07 & -19.06 & -2478.00 \\
\hline
\end{tabular}

There are only three models (Scherer; Barros, Villela) and the G-res tool that calculates both $\mathrm{CO}_{2}$ and $\mathrm{CH}_{4}$ emissions. The only model that calculates the net GHG emission (post-impoundment emission minus pre-impoundment emission minus emissions from unrelated anthropogenic sources) is the G-res tool. It is also the only model that allows estimating GHG emissions related to reservoir construction, and which calculates the emissions related to each use of the reservoir (in the case of multipurpose reservoirs).

Regarding the $\mathrm{CO}_{2}$ emission, the IPCC 2006 model (based on measured emissions) gave the largest emission ( $520 \mathrm{mg} \mathrm{CO} 2 / \mathrm{m}^{2} / \mathrm{d}$ ), followed by the Barros model (which takes into account the reservoir age and dissolved organic carbon $\left(414.35 \mathrm{mg} \mathrm{CO} / \mathrm{m}^{2} / \mathrm{d}\right)$ ), the Scherer model (which takes into account the reservoir age and erosion rate $(327.56 \mathrm{mg}$ $\mathrm{CO}_{2} / \mathrm{m}^{2} / \mathrm{d}$ )), and the G-res tool (which gave the lowest emission $\left(205.48 \mathrm{mg} \mathrm{CO} 2 / / \mathrm{m}^{2} / \mathrm{d}\right)$ ) (post-impoundment) (Figure 2). 


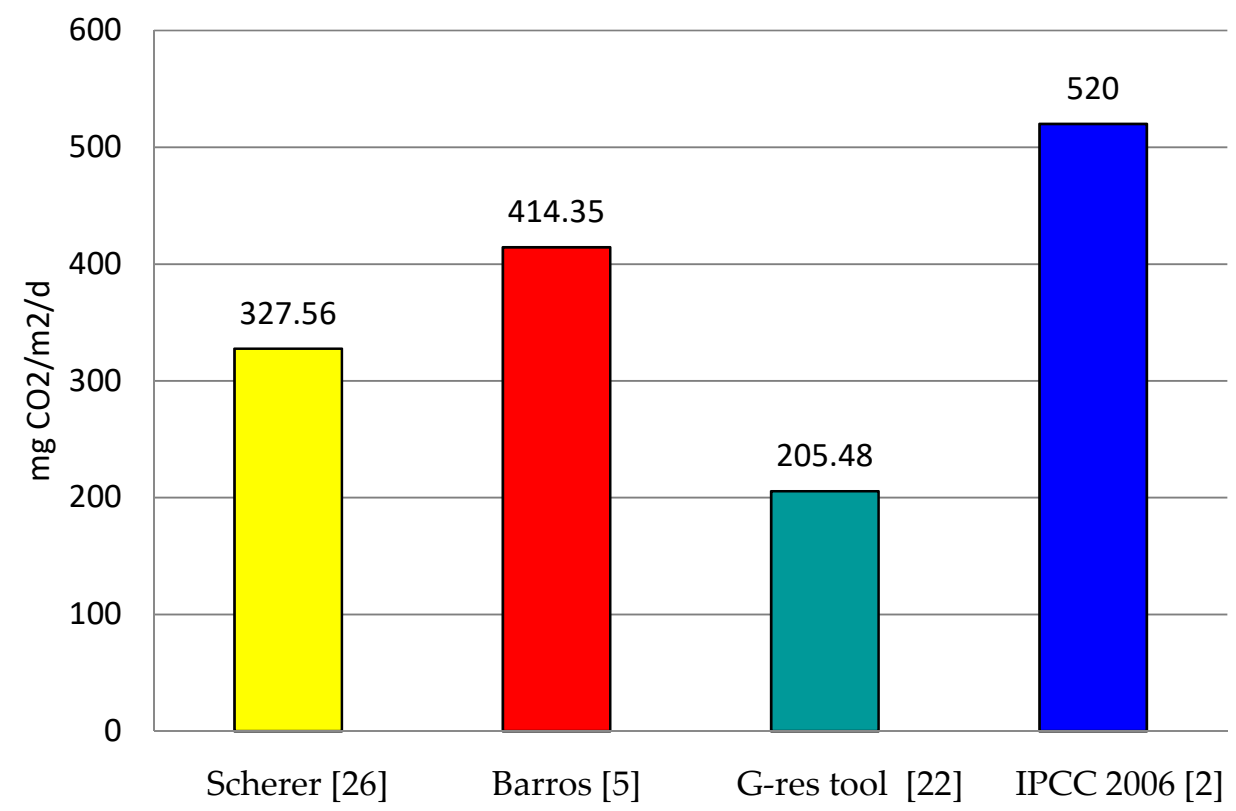

Figure 2. Estimated $\mathrm{CO}_{2}$ emission from the Stânca-Costești multipurpose reservoir.

The values obtained for methane emission can be divided into two groups: a group of high values and a group of low values. The first group includes the Vilela plus Bergier model with $76.52 \mathrm{mg} \mathrm{CH} 4 / \mathrm{m}^{2} / \mathrm{d}$, the Scherer model with $28.57 \mathrm{mg} \mathrm{CH} 4 / \mathrm{m}^{2} / \mathrm{d}$ and the IPCC 2019 model with $13.11 \mathrm{mg} \mathrm{CH} \mathrm{CH}_{4} / \mathrm{m}^{2} / \mathrm{d}$. The second group includes the Bastviken model with $3.91 \mathrm{mg} \mathrm{CH} / \mathrm{m}^{2} / \mathrm{d}$, the G-res tool with $2.42 \mathrm{mg} \mathrm{CH} 4 / \mathrm{m}^{2} / \mathrm{d}$ (postimpoundment) and the Barros model with $1.16 \mathrm{mg} \mathrm{CH}_{4} / \mathrm{m}^{2} / \mathrm{d}$ (Figure 3).

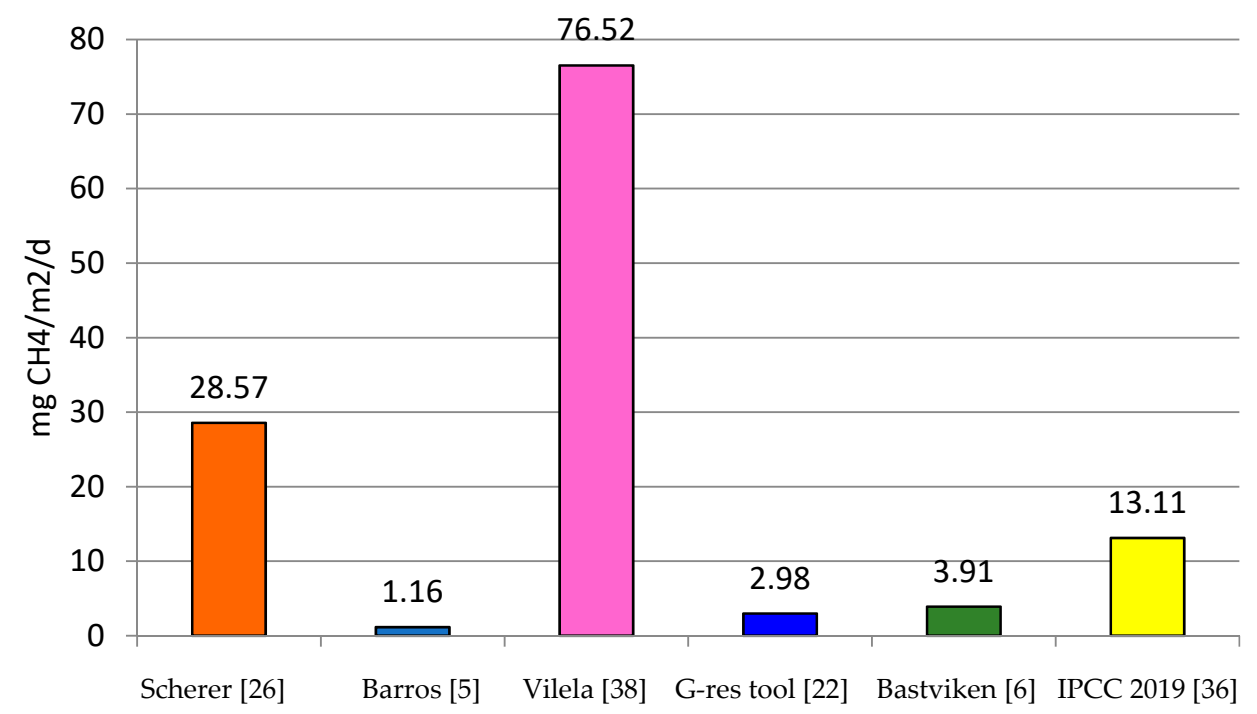

Figure 3. Estimated $\mathrm{CH}_{4}$ emission from the Stânca-Costești multipurpose reservoir.

The G-res tool indicates that the reservoir has a negative net GHG emission of $-819 \mathrm{mg}$ $\mathrm{CO}_{2 \mathrm{eq}} / \mathrm{m}^{2} / \mathrm{d}$, which means that the reservoir is a carbon sink, with a lower emission after impoundment (403 $\mathrm{mg} \mathrm{CO} 2 \mathrm{eq} / \mathrm{m}^{2} / \mathrm{d}$ ) than before impoundment $\left(1222 \mathrm{mg} \mathrm{CO} \mathrm{CO}_{2 \mathrm{eq}} / \mathrm{m}^{2} / \mathrm{d}\right.$ ).

Among the models that calculate the annual global GHG emission, the G-res tool gave the lowest emission (6608 tonne $\mathrm{CO}_{2 \mathrm{eq}} / \mathrm{yr}$ ) (post-impoundment), followed by the Barros model with 9769.44 tonne $\mathrm{CO}_{2 \mathrm{eq}} / \mathrm{yr}$ and the Scherer model with the highest emission of 27,972.67 tonne $\mathrm{CO}_{2 \mathrm{eq}} / \mathrm{yr}$, more than four times higher than the lowest emission.

The calculation of GHG emission from a multipurpose reservoir as function of energy produced (expressed in $\mathrm{kg} \mathrm{CO}_{2 \mathrm{eq}} / \mathrm{MWh}$ ) is not conclusive, as energy generation is one of 
multiple uses. For the studied multipurpose reservoir, given the reduced installed capacity of only $30 \mathrm{MW}$ (and therefore the reduced amount of energy produced, $130 \mathrm{GWh} / \mathrm{yr}$ ) the calculated amount of GHG emitted per unit of energy produced resulted in being two times higher than the IHA estimated emission of hydropower [47] (50.83 $\mathrm{kg} \mathrm{CO}_{2 \mathrm{eq}} / \mathrm{MWh}$ versus of $23 \mathrm{~kg} \mathrm{CO} 2 \mathrm{eq} / \mathrm{MWh}$ ).

The G-res tool solves this shortcoming because it compares the GHG emissions obtained by using it with the emissions of reservoirs of the same type from the same climate zone.

The net reservoir footprint of $-9 \mathrm{~g} \mathrm{CO}_{2 \mathrm{eq}} / \mathrm{m}^{2} / \mathrm{yr}$ is placed at the base of the Gaussian distribution, which ranges from -90 to $+1960 \mathrm{~g} \mathrm{CO}_{2 \mathrm{eq}} / \mathrm{m}^{2} / \mathrm{yr}$ and has a peak near $+210 \mathrm{~g} \mathrm{CO}_{2 \mathrm{eq}} / \mathrm{m}^{2} / \mathrm{yr}$. $\mathrm{CH}_{4}$ diffusive emissions of $+43 \mathrm{~g} \mathrm{CO}_{2 \mathrm{eq}} / \mathrm{m}^{2} / \mathrm{yr}$ is very close to the value that gives the peak of the Gaussian distribution $\left(+40 \mathrm{~g} \mathrm{CO}_{2 \mathrm{eq}} / \mathrm{m}^{2} / \mathrm{yr}\right) \cdot \mathrm{CH}_{4}$ bubbling emissions of $+3 \mathrm{~g} \mathrm{CO}_{2 \mathrm{eq}} / \mathrm{m}^{2} / \mathrm{yr}$ is very close to the value that gives the peak of the Gaussian distribution $\left(0 \mathrm{~g} \mathrm{CO}_{2 \mathrm{eq}} / \mathrm{m}^{2} / \mathrm{yr}\right) . \mathrm{CO}_{2}$ diffusive emissions of $+75 \mathrm{~g} \mathrm{CO}_{2 \mathrm{eq}} / \mathrm{m}^{2} / \mathrm{yr}$ are very close to the value that gives the peak of the Gaussian distribution $\left(+90 \mathrm{~g} \mathrm{CO}_{2 \mathrm{eq}} / \mathrm{m}^{2} / \mathrm{yr}\right)$. $\mathrm{CH}_{4}$ degassing emissions could not be calculated because the reservoir has a deep water intake. However, its contribution to the overall GHG footprint is relatively small (mean: $14 \%$, median: $4 \%$ ) [23]. The allocated GHG emissions intensity of $4.1 \mathrm{~g} \mathrm{CO}_{2 \mathrm{eq}} / \mathrm{kWh}$ is very close to the value that gives the peak of the Gaussian distribution $\left(0 \mathrm{~g} \mathrm{CO}_{2 \mathrm{eq}} / \mathrm{kWh}\right)$. The $\mathrm{CH}_{4}$ post-impoundment emissions have the following distribution: $93 \% \mathrm{CH}_{4}$ diffusive emissions and $7 \% \mathrm{CH}_{4}$ bubbling emissions. The contribution of each use of the reservoir is as follows: $26.7 \%$ flood control; $5 \%$ fisheries; $15 \%$ irrigation; $26.7 \%$ water supply; and $26.7 \%$ hydroelectricity.

Of course, for a preliminary and rapid estimate of GHG emissions from a reservoir, simple models can be used that require only a few reservoir-specific factors. For a more accurate assessment, it is necessary to use a more complex and complete model, such as the G-res tool. The G-res tool offers the possibility to find out the potential impact that the creation of a reservoir can have and also to find out if measures are needed to reduce GHG emissions from a certain reservoir (regardless of the reservoir purpose), or to find out that the emissions of a reservoir may be the result of human activity that is not related to the reservoir creation. When the necessary time and tools are available, it is most desirable to perform long-term measurements to report the actual values of emissions from all sources related to reservoirs (drawdown area, reservoir surface, turbines, spillway and downstream river).

Taking into account the lifecycle GHG emission intensity from Table 8, if the energy produced by the Stânca-Costesti reservoir is produced by a coal-fired power plant, additional GHG emissions of 103,610 tonnes $\mathrm{CO}_{2 \mathrm{eq}} / \mathrm{yr}$ would be generated, and if it was produced by a natural gas-fired power plant, additional GHG emissions of 60,710 tonnes $\mathrm{CO}_{2 \mathrm{eq}} / \mathrm{yr}$ would be generated.

Table 8. Lifecycle GHG emissions for different electricity generation technologies [47].

\begin{tabular}{cc}
\hline Technology & $\begin{array}{c}\text { Lifecycle GHG Emission Intensity } \\
\mathbf{~ k g ~ C O} \text { Ceq }_{\mathbf{e q}} / \mathbf{M W h}\end{array}$ \\
& 820 \\
Thermal-coal & 490 \\
Thermal-natural gas & 230 \\
Biomass & 48 \\
Solar-PV & 23 \\
Hydropower & 12 \\
Nuclear & 12 \\
Wind & \\
\hline
\end{tabular}

\section{Conclusions}

Built to meet human needs, multipurpose reservoirs increase human well-being, but they cause changes in the water quality, ecosystem and flow regime of river networks. They are considered neutral in terms of GHG emissions, but they may become considerable sources of GHG depending, especially, on the climatic zone in which they are located and their uses. The 
creation of a water reservoir on a river leads to the generation of GHG, due to biogeochemical processes in the reservoir. The calculation of GHG emissions of the studied reservoir, which is placed in a temperate zone and has multiple uses of water, shows that they are lower than those of a lake (306.85 $\mathrm{g} \mathrm{CO}_{2 \mathrm{eq}} / \mathrm{m}^{2} / \mathrm{yr}$ versus $953.73 \mathrm{~g} \mathrm{CO}_{2 \mathrm{eq}} / \mathrm{m}^{2} / \mathrm{yr}$ ).

Knowing the GHG emissions from the reservoir is useful to accurately report the greenhouse gas (GHG) emissions. To calculate the $\mathrm{CO}_{2}$ emission, four models were used; to calculate the $\mathrm{CH}_{4}$ emission, six models were used. If the difference between the highest (520 $\mathrm{mg} \mathrm{CO} 2 / \mathrm{m}^{2} / \mathrm{d}$ ) and the lowest $\mathrm{CO}_{2}$ emission value $\left(205.48 \mathrm{mg} \mathrm{CO} / \mathrm{m}^{2} / \mathrm{d}\right.$ ) is more than two-fold, the difference between the highest $\mathrm{CH}_{4}$ emission $\left(76.52 \mathrm{mg} \mathrm{CH}_{4} / \mathrm{m}^{2} / \mathrm{d}\right)$ and the lowest emission value $\left(1.16 \mathrm{CH}_{4} \mathrm{mg} \mathrm{CH}_{4} / \mathrm{m}^{2} / \mathrm{d}\right)$ is much larger, by about 65 times.

Because not all the methodologies reviewed make an overall assessment of GHG emissions and because some are used only for hydropower reservoirs-except the G-res tool, which estimates the GHG emissions from the reservoir surface, drawdown, turbines and spillway-it is difficult to compare the results obtained by applying the methodologies to the multipurpose reservoir, Stânca-Costești.

In the absence of a standardized methodology for calculating GHG emissions from the reservoirs, the reviewed models can be used in correlation with the available data on reservoirs.

Author Contributions: Conceptualization, I.V.I. and A.E.; methodology, I.V.I.; software, I.V.I.; validation, I.V.I. and A.E.; formal analysis, I.V.I.; investigation, I.V.I. and A.E.; resources, I.V.I. and A.E.; data curation, I.V.I. and A.E.; writing—original draft preparation, I.V.I.; writing—review and editing, I.V.I. and A.E.; visualization, I.V.I. and A.E.; supervision, A.E.; project administration, A.E.; funding acquisition, A.E. All authors have read and agreed to the published version of the manuscript.

Funding: This work was supported by the project with code BSB 165 "HydroEcoNex", funded by the European Union through the Joint Operational Programme "Black Sea Basin 2014-2020". The content of this publication is the sole responsibility of the authors, and in no case should it be considered to reflect the views of the European Union. The APC is funded by "Dunarea de Jos" University of Galati, Romania, grant no. RF 3621/2021.

Institutional Review Board Statement: Not applicable.

Informed Consent Statement: Not applicable.

Data Availability Statement: The data that support the findings of this study are available from the authors upon reasonable request.

Acknowledgments: The authors are grateful to the "Romanian Waters" National Administration for providing, on request, construction and operation data of the reservoir, Stânca-Costești, and to the International Hydropower Association (IHA) for the permission to use the GHG reservoir (G-res) tool.

Conflicts of Interest: The authors declare no conflict of interest. The funders had no role in the design of the study; in the collection, analyses, or interpretation of data; in the writing of the manuscript, or in the decision to publish the results.

\section{References}

1. Levasseur, A.; Mercier-Blais, S.; Prairie, Y.T.; Tremblay, A.; Turpin, C. Improving the accuracy of electricity carbon footprint: Estimation of hydroelectric reservoir greenhouse gas emissions. Renew. Sust. Energ. Rev. 2021, 136, 110433. [CrossRef]

2. IPCC (Intergovernmental Panel on Climate Change). 2006 IPCC Guidelines for National Greenhouse Gas Inventories; Eggleston, H.S., Buendia, L., Miwa, K., Ngara, T., Tanabe, K., Eds.; Institute for Global Environmental Strategies (IGES): Kanagawa, Japan, 2006.

3. World Bank. Greenhouse Gases from Reservoirs Caused by Biogeochemical Processes; World Bank: Washington, DC, USA, 2017. Available online: https:/ / openknowledge.worldbank.org/handle/10986/29151 (accessed on 16 December 2020).

4. Almeida, R.M.; Paranaíba, J.R.; Barbosa, Í; Sobek, S.; Kosten, S.; Linkhorst, A.; Mendonça, R.; Quadra, G.; Roland, F.; Barros, N. Carbon dioxide emission from drawdown areas of a Brazilian reservoir is linked to surrounding land cover. Aquat. Sci. 2019, 81, 68. [CrossRef]

5. Barros, N.; Cole, J.J.; Tranvik, L.J.; Prairie, Y.T.; Bastviken, D.; Huszar, V.L.M.; del Giorgio, P.; Roland, F. Carbon emission from hydroelectric reservoirs linked to reservoir age and latitude. Nat. Geosci. 2011, 4, 593-596. [CrossRef]

6. Bastviken, D.; Cole, J.; Pace, M.; Tranvik, L. Methane emissions from lakes: Dependence of lake characteristics, two regional assessments, and a global estimate. Glob. Biogeochem. Cycles 2004, 18, GB4009. [CrossRef] 
7. Bastviken, D.; Tranvik, L.J.; Downing, J.A.; Crill, P.M.; Enrich-Prast, A. Freshwater methane emissions offset the continental carbon sink. Science 2011, 331, 50. [CrossRef]

8. Chen, H.; Wu, Y.Y.; Yuan, X.Z.; Gao, Y.S.; Wu, N.; Zhu, D. Methane emissions from newly created marshes in the drawdown area of the Three Gorges Reservoir. J. Geophys. Res. 2009, 114, D18301. [CrossRef]

9. Chen, Z.; Ye, X.; Huang, P. Estimating Carbon Dioxide $\left(\mathrm{CO}_{2}\right)$ Emissions from Reservoirs Using Artificial Neural Networks. Water 2018, 10, 26. [CrossRef]

10. Deemer, B.R.; Harrison, J.A.; Li, S.; Beaulieu, J.J.; Delsontro, T.; Barros, N.; Bezerra-Neto, J.F.; Powers, S.M.; Dos Santos, M.A.; Vonk, J.A. Greenhouse gas emissions from reservoir water surfaces: A new global synthesis. Bioscience 2016, 66, 949-964. [CrossRef]

11. Du, H.L.; Li, Z.; Guo, J.S. Carbon footprint of a large hydropower project in the upstream of the Yangtze: Following ISO14067. Resour. Environ. Yangtze Basin 2017, 26, 1102-1110.

12. Gallagher, J.; Styles, D.; McNabola, A.; Williams, A.P. Life cycle environmental balance and greenhouse gas mitigation potential of micro-hydropower energy recovery in the water industry. J. Clean Prod. 2015, 99, 152-159. [CrossRef]

13. Galy-Lacaux, C.; Delmas, R.; Kouadio, J.; Richard, S.; Gosse, P. 1999, Long-term Greenhouse Gas Emissions from Hydroelectric Reservoirs in Tropical Forest Regions. Glob. Biogeochem. Cycles 1999, 13, 503-517. [CrossRef]

14. Jiang, T.; Shen, Z.; Liu, Y.; Hou, Y. Carbon Footprint Assessment of Four Normal Size Hydropower Stations in China. Sustainability 2018, 10, 2018. [CrossRef]

15. Kadiyala, A.; Kommalapati, R.; Huque, Z. Evaluation of the Life Cycle Greenhouse Gas Emissions from Hydroelectricity Generation Systems. Sustainability 2016, 8, 539. [CrossRef]

16. Li, S.; Zhang, Q. Carbon emission from global hydroelectric reservoirs revisited. Environ. Sci. Pollut. Res. 2014, $21,13636-13641$. [CrossRef] [PubMed]

17. Li, X.; Gui, F.; Li, Q. Can Hydropower Still Be Considered a Clean Energy Source? Compelling Evidence from a Middle-Sized Hydropower Station in China. Sustainability 2019, 11, 4261. [CrossRef]

18. Mäkinen, K.; Khan, S. Policy considerations for greenhouse gas emissions from freshwater reservoirs. Water Altern. 2010, 3 , 91-105.

19. Mosher, J.J.; Fortner, A.M.; Phillips, J.R.; Bevelhimer, M.S.; Stewart, A.J.; Troia, M.J. Spatial and Temporal Correlates of Greenhouse Gas Diffusion from a Hydropower Reservoir in the Southern United States. Water 2015, 7, 5910-5927. [CrossRef]

20. Prakash, R.; Bhat, I.K. Life cycle greenhouse gas emissions estimation for small hydropower schemes in India. Energy 2012, 44, 498-508.

21. Prairie, Y.T.; Alm, J.; Beaulieu, J.; Barros, N.; Battin, T.; Cole, J.; del Giorgio, P.; Del Sontro, T.; Guérin, F.; Harby, A.; et al. Greenhouse gas emissions from freshwater reservoirs: What does the atmosphere see? Ecosystems 2017, 21, 1058-1071. [CrossRef]

22. Prairie, Y.T.; Alm, J.; Harby, A.; Mercier-Blais, S.; Nahas, R. The GHG Reservoir Tool (Gres) Technical documentation v2.1 (2019-08-21). UNESCO/IHA research project on the GHG status of freshwater reservoirs; Joint publication of the UNESCO Chair in Global Environmental Change and the International Hydropower Association: London, UK, 2017. Available online: https://www. hydropower.org/publications/the-ghg-reservoir-tool-g-res-technical-documentation (accessed on 30 March 2021).

23. Prairie, Y.T.; Mercier-Blais, S.; Harrison, J.A.; Soued, C.; Del Giorgio, P.; Harby, A.; Alm, J.; Chanudet, V.; Nahas, R. A new modelling framework to assess biogenic GHG emissions from reservoirs: The G-res, tool. Environ. Model Softw. 2021, $143,105117$. [CrossRef]

24. Rosa, L.P.; dos Santos, M.A.; Matvienko, B.; Sikar, E. Hydroelectric reservoirs and global warming. In Proceedings of the RIO 02-World Climate and Energy Event, Rio de Janeiro, Brazil, 6-11 January 2002; pp. 123-129. Available online: http: //www.rio12.com/rio02/proceedings/pdf/123_Rosa.pdf (accessed on 10 April 2021).

25. Rosa, L.P.; dos Santos, M.A.; Matvienko, B.; dos Santos, E.O.; Sikar, E. Greenhouse Gases Emissions by Hydroelectric Reservoirs in Tropical Regions. Clim. Chang. 2004, 66, 9-21. [CrossRef]

26. Scherer, L.; Pfister, S. Hydropower's Biogenic Carbon Footprint. PLoS ONE 2016, 11, e0161947. [CrossRef]

27. Song, C.; Gardner, K.H.; Klein, S.J.W.; Souza, S.P.; Mo, W. Cradle-to-grave greenhouse gas emissions from dams in the United States of America. Renew. Sustain. Energ. Rev. 2018, 90, 945-956. [CrossRef]

28. St. Louis, V.L.; Kelly, C.A.; Duchemin, É; Rudd, J.W.M.; Rosenberg, D.M. Reservoir surfaces as sources of greenhouse gases to the atmosphere: A global estimate. BioScience 2000, 50, 766-775. [CrossRef]

29. Suwanit, W.; Gheewala, S.H. Life cycle assessment of mini-hydropower plants in Thailand. Int. J. LCA 2011, 16, 849-858. [CrossRef]

30. Zhang, Q.F.; Karney, B.; MacLean, H.L.; Feng, J.C. Life-cycle inventory of energy use and greenhouse gas emissions for two hydropower projects in China. J. Infrastruct. Syst. 2007, 13, 271-279. [CrossRef]

31. Zhang, S.R.; Pang, B.H.; Zhang, Z.L. Carbon footprint analysis of two different types of hydropower schemes: Comparing earth-rockfill dams and concrete gravity dams using hybrid life cycle assessment. J. Clean Prod. 2015, 103, 854-862. [CrossRef]

32. Schlömer, S.; Bruckner, T.; Fulton, L.; Hertwich, E.; McKinnon, A.; Perczyk, D.; Roy, J.; Schaeffer, R.; Sims, R.; Smith, P.; et al. Annex III: Technology-specific cost and performance parameters. In Climate Change 2014: Mitigation of Climate Change. Contribution of Working Group III to the Fifth Assessment Report of the Intergovernmental Panel on Climate Change; Edenhofer, O., Pichs-Madruga, R., Sokona, Y., Minx, J.C., Farahani, E., Kadner, S., Seyboth, K., Adler, A., Baum, I., Brunner, S., et al., Eds.; Cambridge University Press: New York, NY, USA, 2014. 
33. Myhre, G.; Shindell, D.; Bréon, F.M.; Collins, W.; Fuglestvedt, J.; Huang, J.; Koch, D.; Lamarque, J.F.; Lee, D.; Mendoza, B.; et al. Anthropogenic and Natural Radiative Forcing. In Climate Change 2013: The Physical Science Basis. Contribution of Working Group I to the Fifth Assessment Report of the Intergovernmental Panel on Climate Change; Stocker, T.F., Qin, D., Plattner, G.-K., Tignor, M., Allen, S.K., Boschung, J., Nauels, A., Xia, Y., Bex, V., Midgley, P.M., Eds.; Cambridge University Press: Cambridge, UK; New York, NY, USA, 2013.

34. Li, Z.; Du, H.L.; Xiao, Y.; Guo, J.S. Carbon footprints of two large hydro-projects in China: Life-cycle assessment according to ISO/TS 14067. Renew. Energy 2017, 114, 534-546. [CrossRef]

35. IEA Hydropower. Annex XII: Guidelines for Quantitative Analysis of Net GHG Emissions from Reservoirs. 2012. Available online: https: / / www.ieahydro.org/publications/iea-hydro-reports (accessed on 23 November 2020).

36. Lovelock, C.E.; Evans, C.; Barros, N.; Prairie, Y.; Alm, J.; Bastviken, D.; Beaulieu, J.J.; Garneau, M.; Harby, A.; Harrison, J.; et al. 2019 Refinement to the 2006 IPCC Guidelines for National Greenhouse Gas Inventories, Volume 4: Agriculture, Forestry and Other Land Use (Chapter 7: Wetlands); IPCC: Kanagawa, Japan, 2019.

37. Goldenfum, J.A. (Ed.) UNESCO/IHA GHG Measurement Guidelines for Freshwater Reservoirs; International Hydropower Association (IHA): London, UK, 2010.

38. Vilela, T.; Reid, J. Improving hydropower choices via an online and open access tool. PLoS ONE 2017, 12, e0179393. [CrossRef]

39. Bergier, I.; Bambace, L.; Ramos, F.M. GHG life cycle analysis and novel opportunities arising from emerging technologies developed for tropical dams. In Proceedings of the UNESCO-IHP Workshop on the Greenhouse Gas Status of Freshwater Reservoirs, Foz do Iguaçu, Brazil, 4-5 October 2007. Available online: https://www.researchgate.net/publication/323073 413_GHG_LIFE_CYCLE_ANALYSIS_AND_NOVEL_OPPORTUNITIES_ARISING_FROM_EMERGING_TECHNOLOGIES_ DEVELOPED_FOR_TROPICAL_DAMS (accessed on 15 April 2021).

40. Corobov, R.; Ene, A.; Trombitsky, I.; Zubcov, E. The Prut River under Climate Change and Hydropower Impact. Sustainability 2021, 13, 66. [CrossRef]

41. Dumitran, G.E.; Vuta, L.I.; Popa, B.; Popa, F. Hydrological Variability Impact on Eutrophication in a Large Romanian Border Reservoir, Stânca-Costesti. Water 2020, 12, 3065. [CrossRef]

42. Zomer, R.J.; Bossio, D.A.; Sommer, R.; Verchot, L.V. Global Sequestration Potential of Increased Organic Carbon in Cropland Soils. Sci. Rep. 2017, 7, 15554. [CrossRef] [PubMed]

43. Panagos, P.; Borrelli, P.; Poesen, J.; Ballabio, C.; Lugato, E.; Meusburger, K.; Montanarella, L.; Alewell, C. The new assessment of soil loss by water erosion in Europe. Environ. Sci. Policy 2015, 54, 438-447. [CrossRef]

44. Available online: https://planiada.ro/destinatii/botosani/lacul-stanca-costesti-289 (accessed on 15 January 2021).

45. Available online: https://www.hidroconstructia.com/dyn/2pub/proiecte_det.php?id=114\&pg=8 (accessed on 15 January 2021).

46. Fekete, B.M.; Vörösmarty, C.J.; Grabs, W. Global Composite Runoff Fields Based on Observed River Discharge and Simulated Water Balances. In UNH/GRDC Composite Runoff Fields v1.0; Complex Systems Research Center, University of New Hampshire: Durham, NH, USA; Global Runoff Data Center: Koblenz, Germany, 2000. Available online: http://www.grdc.sr.unh.edu (accessed on 1 December 2020).

47. International Hydropower Association (IHA). Carbon Emissions from Hydropower Reservoirs: Facts and Myths, 2021. Available online: https: / www.hydropower.org/blog/carbon-emissions-from-hydropower-reservoirs-facts-and-myths (accessed on 12 April 2021). 